\title{
MENINGKATKAN KEMAMPUAN BERPIKIR KREATIF MATEMATIS DAN KEMANDIRIAN BELAJAR SISWA SMP MELALUI PENDEKATAN SAINTIFIK BERBASIS ETNOMATEMATIKA
}

\author{
${ }^{1)}$ Ratna Sariningsih, ${ }^{2}$ Gida Kadarisma \\ ratnasari_ning@ymail.com \\ ${ }^{1.2}$ Program Studi Pendidikan Matematika, STKIP Siliwangi \\ ABSTRAK
}

\begin{abstract}
Penelitian ini dilatarbelakangi oleh rendahnya kemampuan berpikir kreatif Matematis siswa Sekolah Menengah Pertama. Penelitan ini bertujuan untuk mengetahui perbedaan pencapaian \& peningkatan kemampuan berpikir kreatif dan kemandirian belajar matematik siswa serta asosiasi antara yang memperoleh pendekatan saintifik biasa dengan yang memperoleh pendekatan saintifik berbasis etnomatematika. Metode penelitian ini adalah eksperimen dengan disain pretest postest control group design dengan populasi penelitian ini siswa kelas VIII di salah satu SMP Negeri di Kota Bandung, sampelnya diambil dua kelas dari 9 kelas yang ada. Instrumen dalam penelitian ini adalah tes uraian kemampuan berpikir kritis \& kreatif matematis sebanyak 5 soal. Berdasarkan hasil penelitian Terdapat Perbedaan Pencapaian \& peningkatan Kemampuan Berpikir Kreatif matematis siswa SMP yang pembelajarannya menggunakan PendekatanSaintifik biasa dengan yang menggunakan Pendekatan Saintifik berbasis etnomatematika, serta tidak terdapat perbedaan Kemandirian Belajar siswa yang pembelajarannya menggunakan Pendekatan Saintifik dengan yang memperoleh pendekatan saintif berbasis Etnomatematika dan Terdapat asosiasi antarakemampuan Berpikir Kreatif matematis siswa dengan kemandirian belajar siswa yang pembelajarannya menggunakan Pendekatan Saintifik berbasis etnomatematika.
\end{abstract}

Kata Kunci : Berpikir Kreatif Matematis , Kemandirian Belajar, Etnomatematika

\begin{abstract}
This research is motivated by the lack of ability to think creatively Mathematically junior secondary students. This research aims to determine differences in achievement and increase the ability of creative thinking and independent learning as well as the association between mathematics student who obtained the usual scientific approach to obtaining scientific approach based etnomatematika. This research method is experimental design with pretest posttest control group design in this study population eighth grade students in one of the Junior High School in Bandung, the sample was taken two classes of ninth grade there. Instruments in this study is a test description of critical and creative thinking skills as much as 5 mathematical problems. Based on the results of the study are Differences in Achievement and improvement Ability Creative Thinking Mathematically junior high school students are learning to use PendekatanSaintifik usual with the use Approach Scientific based etnomatematika, and there is no difference Independence Learning student learning using the approach Scientific with the gain approaches saintif based Etnomatematika and are associated antarakemampuan Creative Thinking Mathematically students with learning independence student learning using etnomatematika-based Scientific Approach.
\end{abstract}

Keywords: Creative Thinking Mathematically, Independence Learning, Etnomatematika

\section{A. PENDAhUluan}

Pembelajara matematika memiliki fungsi sebagai sarana untuk mengembangkan kemampuan berpikir kritis, logis, kreatif, dan bekerjasama yang diperlukan siswa dalam kehidupan yang semakin maju ini. Seperti tercantum dalam standar isi untuk satuan pendidikan dasar dan menengah mata pelajaran matematika bahwa mata pelajaran matematika perlu diberikan kepada semua peserta didik dari sekolah dasar untuk membekali peserta didik dengan kemampuan berpikir logis, analitis, sistematis, kritis, dan kreatif serta bekerjasama.

Dengan demikian, kompetensi tersebut diperlukan agar peserta didik dapat memiliki kemampuan memperoleh, mengelola dan memanfaatkan informasi untuk bertahan hidup pada keadaaan yang selalu beubah, tidak pasti, dan kompetitif (Peraturan Mentri Pendidikan Nasional nomor 22 tahun 2006 tentang standar isi). Oleh karena itu, pembelajaran matematika memiliki sumbangan yang penting untuk perkembangan kemampuan berpikir kreatif dalam setiap individu siswa agar menjadi sumber manusia yang berkualitas.

Kemampuan siswa mengatur diri dalam belajar disebut dengan kemandirian belajar. Kemampuan untuk mengatur diri dalam belajar matematika berperan dalam meningkatkan kualitas dan kuantitas diri dalam belajar. Pada dasarnya, kemandirian belajar menempatkan pentingnya kemampuan seseorang untuk mengatur dan mengendalikan diri sendiri, terutama bila menghadapi permasalahan. 
Pembelajaran dengan Pendekatan Saintifik merupakan proses pembelajaran yang dirancang sedemikian rupa agar peserta didik secara aktif mengonstruk konsep, hukum atau prinsip melalui tahapan-tahapan mengamati (untuk mengidentifikasi atau menemukan masalah), merumuskan masalah, mengajukan atau merumuskan hipotesis, mengumpulkan data dengan berbagai teknik, menganalisis data, menarik kesimpulan dan mengomunikasikan konsep, hukum atau prinsip yang "ditemukan".

Perkembangan budaya menjadi perhatian belakangan ini, hal ini selaras dengan negara Indonesia sebagai negara yang kaya akan budaya. Pendidikan budaya dapat kita impilisitkan dalam pembelajaran disekolah, contohnya dalam pembelajaran matematika. Nilai budaya matematika terpancar dari peran matematika dalam dunia seni, serta penampakan matematika dalam menunjukkan tingkat peradaban manusia.

Pembelajaran matematika di sekolah pada dasarnya dapat menjadi awal pembentukan masyarakat maju. Dalam pembelajaran matematika guru tidak selayaknya hanya memberikan simbolsimbol abstrak dan teorema yang membosankan bagi sebagian besar siswa, karena melalui penyampaian tujuan pembelajaran yang jelas dan pendekatan realistis, matematika akan menjadi teman keseharian siswa. Pembelajaran matematika yang mengusung kepada kearifan lokal sering kita dengar dengan istilah etnomatematika. Etnomatematika bisa didefinisikan sebagai caracara khusus yang dilakukan oleh suatu kelompok tertentu dalam melakukan aktifitas matematika. Bentuk dari etnomatematika berupa hasil dari aktivitas matematika yang dimiliki atau berkembang pada kelompok itu sendiri.

\section{B. KAJIAN TEORI DAN METODE \\ 1. Kajian Teori}

\section{a. Kemampuan Berpikir Kreatif Matematik}

Kemampuan kreatif secara umum dipahami sebagai kreativitas. Pada umumnya, individu yang dianggap kreatif adalah pemikir sintesis yang benar-benar baik yang membangun koneksi antara berbagai hal yang tidak disadari orang-orang lain secara spontan. Berkenaan dengan hal tersebut (Sternberg, 2007) mengemukakan bahwa dalam hal mengembangkan kemampuan berpikir kreatif ada beberapa strategi yang digunakan antara lain:

1) Mendefinisikan kembali masalah

2) Mempertanyakan dan menganalisis asumsiasumsi

3) Menjual ide-ide kreatif
4) Membangkitkan ide-ide

5) Mengenali dua sisi pengetahuan

6) Mengidentifikasi dan mengatasi hambatan

7) Mengambil resiko-resiko dengan bijak

8) Menoleransi ambiguitas (kemenduan)

9) Membangun kecakapan diri

10) Menemukan minat sejati

11) Menunda kepuasan

12) Membuat model kreativitas.

\section{b. Kemandirian Belajar}

Kemandirian belajar menurut Bandura (Nur, 2000) adalah seseorang yang memiliki pengetahuan tentang strategi belajar efektif dan bagaimana serta kapan menggunakan pengetahuan itu. Lebih dari itu, Schunk (Nur, 2000) menyatakan bahwa seseorang yang mempunyai kemandirian belajar memiliki kemampuan untuk mengatur motivasi dirinya, tidak saja motivator eksternal tetapi juga motivator internal serta mereka mampu tetap menekuni tugas jangka panjang sampai tugas itu diselesaikan.

Diagram berikut menunjukkan ketiga tahap siklus kemandirian belajar, bersama dengan refleksinya dapat digambarkan seperti berikut (Fahinu, 2007):

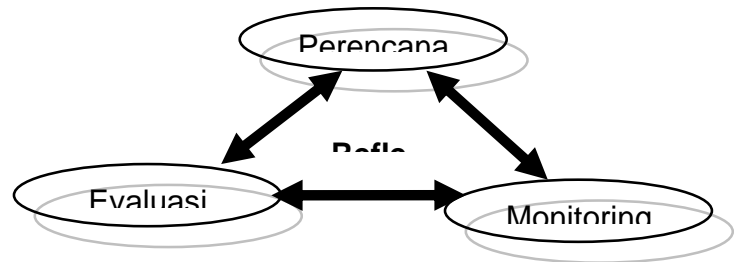

\section{Gambar 2. Siklus Kemandirian Belajar}

Tahap Perencanaan, pada tahap ini menetapkan langkah-langkah untuk belajar, yaitu (1) Menganalisis tugas belajar, (2) Menentukan tujuan belajar, dan (3) Merencanakan strategi belajar. Tahap Monitoring, pada tahap ini menerapkan rencana dengan terus-menerus dimonitor untuk meyakinkan mengarah ke tujuan belajar. Tahap evaluasi, pada tahap ini menentukan seberapa baik strategi belajar yang dipilih dan bagaimana pencapaian tujuan belajar tersebut. Refleksi, menyediakan hubungan-hubungan antara ketiga tahapan dalam memahami pelajaran (metakognitif pengetahuan).

\section{c. Pembelajaran Saintifik}

Pembelajaran saintifik merupakan pembelajaran yang mengadopsi langkah-langkah saintis dalam membangun pengetahuan melalui metode ilmiah. Dalam proses pembelajaran menyentuh tiga ranah yaitu sikap, pengetahuan dan keterampilan.Hal ini sesuai dengan perubahan paradigma pembelajaran 
dari teacher center menjadstudents center. Pembelajaran tidak lagi terpusat kepada guru, melainkan kepada anak didik. Anak didik tidak dianggap lagi sebagai selembar kertas putih ataupun gelas kosong.

Peranan guru yaitu merancang pembelajaran, mengenali tingkat pengetahuan individu anak didik dan memotivasi perserta didik untuk meningkatkan keberhasilan anak didik dan disiapkan kondisi belajar yang menyenangkan. Dalam bahasa lebih singkatnya guru harus mampu menguasai materi dan kelas.

Sebelum penerapan pembelajaran saintifik, alangkah baiknya guru menyiapkan anak didik secara psikis maupun fisik. Unsur persiapan memeranankan hal yang penting untuk keberhasilan tujuan pembelajaran. Guru harus menjelaskan tujuan pembelajaran atau kompetensi dasar yang akan dicapai dan menyampaikan garis besar cakupan materi dan penjelasan tentang kegiatan yang akan dilakukan oleh anak didik.

\section{d. Pembelajaran Berbasis Etnomatematika}

Etnomatematika merupakan matematika yang tumbuh dan berkembang dalam kebudayaan tertentu (Yusuf dkk, 2010). Budaya yang dimaksud disini mengacu pada kumpulan norma atau aturan umum yang berlaku di masyarakat, kepercayaan, dan nilai yang diakui pada kelompok masyarakat yang berada pada suku atau kelompok bangsa yang sama.

Istilah etnomatematika berasal dari kata ethnomathematics, yang terbentuk dari kata ethno,mathema, dan tics (Yusuf dkk, 2010) Awalan ethnomengacu pada kelompok kebudayaan yang dapat dikenali, seperti perkumpulan suku di suatu negara dan kelas-kelas profesi di masyarakat, termasuk pula bahasa dan kebiasaan mereka sehari-hari. Kemudian, mathemadisini berarti menjelaskan, mengerti, dan mengelola hal-hal nyata secara spesifik dengan menghitung, mengukur, mengklasifikasi, mengurutkan, dan memodelkan suatu pola yang muncul pada suatu lingkungan. Akhiran tics mengandung arti seni dalam teknik.

Etnomatematika bisa didefinisikan sebagai caracara khusus yang dialakukan oleh suatu kelompok tertentu dalam melakukan aktifitas matematika. Bentuk dari etnomatematika berupa hasil dari aktivitas matematika yang dimiliki atau berkembang pada kelompok itu sendiri, meliputi konsep matematika pada peniggalan budaya berupa candi dan prasasti, peralatan tradisional, permainan tradisional, dan berbagai macam hasil aktivitas yangtujuan dari adanya etnomatematika adalah untuk mengakui bahwa ada cara-cara berbeda dalam melakukan matematika dengan mempertimbangkan pengetahuan matematika yang dikembangkan dalam berbagai sektor masyarakat serta dengan mempertimbangkan cara yang berbeda dalam aktivitas masyarakat seperti cara mengelompokkan, berhitung, mengukur, merancang bangunan atau alat, bermain dan lainnya.

\section{Metode}

Penelitian ini dilakukan pada siswa SMP yang dikelompokkan kedalam dua kelas, yaitu kelas pertama menggunakan model Learning Cycle 5E, kelas kedua mendapat pembelajaran dengan model discovery learning. Populasi yang akan diteliti adalah seluruh siswa kelas VII pada tahun ajaran 2015/2016 di Bandung yang sudah menerapkan kurikulum 2013. Sampel terdiri dari 2 kelas kemudian dari kedua kelas tersebut ditentukan satu kelas sebagai kelas eksperimen 1 yang mendapat pembelajaran dengan pendekatan saintifik berbasis etnomatematika, sedangkan kelas lainnya yaitu kelas eksperimen 2 dengan pendekatan saintifik biasa sesuai buku pegangan guru.

Pada desain ini, subjek tidak dikelompokkan secara acak kelas, sebelum pembelajaran kedua kelas diberikan pretes kepada kedua kelas, kemudian diberikan postes diakhir eksperimen, desain penelitian ini adalah sebagai berikut:

$$
\begin{array}{ll}
\text { A : } \mathrm{O} & X_{1} \mathrm{O} \\
\mathrm{A}: \mathrm{O} & X_{2} \mathrm{O}
\end{array}
$$

Keterangan:

A : Subjek dikelompokan secara acak kelas

$\mathrm{O}:$ Pretes $=$ Postes

$X_{1}$ : Pembelajaran dengan pendekatan saintifik berbasis etnomatematika

$X_{2}$ : Pembelajaran dengan pendekatan saintifik biasa

\section{HASIL DAN PEMBAHASAN}

Berikut ini disajikan temuan mengenai pencapaian dan peningkatan Berpikir Kreatif dan kemandirian belajar siswa:

Berdasarkan hasil analisis data di atas, diperoleh interpretasi sebagai berikut:

1. Terdapat Perbedaan Pencapaian KemampuanBerpikirKreatif matematissiswa SMP yang pembelajarannya menggunakan PendekatanSaintifik biasa dengan yang menggunakan Pendekatan Saintifik . Rata-rata Keduakelas yaituPendekatanSaintifik $\quad(12,4$ dari skor ideal 20)danPendekatanSaintifik 
berbasis Etnomatematika(14,25 dari skor ideal 20)tergolongkategoriCukup.

2. Terdapat perbedaan Peningkatan Kemampuan Berpikir Kreatif matematissiswa yang pembelajarannya menggunakan Pendekatan Saintifik $(0,49)$ dan Pendekatan Saintifik berbasis Etnomatematika $(0,61)$.

3. Tidak terdapat perbedaan Kemandirian Belajar siswa yang pembelajarannya menggunakan PendekatanSaintifik dengan yang memperoleh pendekatan saintif berbasis Etnomatematika. Namun demikian kemandirianbelajarsiswa pada kedua kelas pembelajaran tergolong tinggi (102.475 dan 105.35dari skor ideal 135).

\section{KESIMPULAN}

Berdasarkan analisis data dan pembahasan, dapat disimpulkan:

1. Terdapat Perbedaan Pencapaian Kemampuan Berpikir Kreatif matematis siswa SMP yang pembelajarannya menggunakan Pendekatan

2. Saintifik biasa dengan yang menggunakan Pendekatan Saintifik berbasis etnomatematika.

Tabel 1. Rekapitulasi Hasil Uji Perbedaan Rerata dengan Uji-t

\begin{tabular}{|l|l|l|}
\hline $\begin{array}{c}\text { Kemampuan dan Kemandirian Belajar } \\
\text { Matematis }\end{array}$ & Sig. & \multicolumn{1}{c|}{ Interpretasi } \\
\hline Pencapaian Berpikir kreatif Matematis & 0.005 & $\begin{array}{l}\text { Terdapat Perbedaan Pencapaian } \\
\text { KemampuanBerpikirKreatifMatematissiswa, yang } \\
\text { pembelajarannya menggunakan PendekatanSaintifik biasa } \\
\text { dengan pendekatan Saintifik berbasis Etnomatematika } \\
\text { pada taraf signifikansi 5\% }\end{array}$ \\
\hline Peningkatang Berpikir Kreatif Matematis & 0,013 & $\begin{array}{l}\text { Terdapat perbedaan Peningkatan } \\
\text { KemampuanBerpikirKreatif Matematissiswa yang } \\
\text { pembelajarannya menggunakan PendekatanSaintifik cara } \\
\text { biasadengan pendekatan Saintifik berbasis } \\
\text { Etnomatematikapada taraf signifikansi 5\% }\end{array}$ \\
\hline KemandirianBelajar & 0.75 & $\begin{array}{l}\text { Tidak terdapat Perbedaan KemandirianBelajarsiswa, yang } \\
\text { pembelajarannya menggunakan PendekatanSaintifik biasa } \\
\text { dengan Pendekatan Saintifik berbasi Etnomatematika } \\
\text { pada taraf signifikansi 5\% }\end{array}$ \\
\hline
\end{tabular}

3. Terdapat perbedaan Peningkatan Kemampuan Berpikir Kreatif matematis siswa yang pembelajarannya menggunakan Pendekatan saintifik dan Pendekatan Saintifik berbasis Etnomatematika.

4. Tidak terdapat perbedaan Kemandirian Belajar siswa yang pembelajarannya menggunakan Pendekatan Saintifik dengan yang memperoleh pendekatan saintif berbasis Etnomatematika.

5. Terdapat asosiasi antarakemampuan Berpikir Kreatif matematis siswa dengan kemandirian belajar siswa yang pembelajarannya menggunakan PendekatanSaintifik berbasis etnomatematika.

\section{E. DAFTAR PUSTAKA}

Fahinu. (2007). Meningkatkan Kemampuan Berpikir Kritis dan Kemandirian Belajar Matematika pada Mahasiswa melalui Pembelajaran Generatif. Disertasi pada SPs UPI Bandung: Tidak diterbitkan.

Filsaime, K. D. (2007). Menguak Rahasia Berpikir Kritis dan Kreatif. Jakarta:PrestasiPustaka.

Nur, M. (2000). Pengajaran Berpusa tkepada Siswa dan Pendekatan Konstruktivis dalam Pengajaran.PPS Universitas Negeri Surabaya.
Sternberg R, et al. (2007). Teaching For Succes full intelegence. Mengajarkan Kecerdasan Sukses. Meningkatkan Pembelajaran dan Keberhasilan Siswa. Penerjemah: Mardiatmoko. G. Yogyakarta: Pustaka Pelajar.

Sumarmo, U. (2004). Kemandirian Belajar: Apa, Mengapa, dan Bagaimana Dikembangkan pada Peserta Didik. Makalah pada Seminar Tingkat Nasional. FPMIPA UNY Yogyakarta Tanggal 8 Juli 2004.

Turmudi. (2008). Landasan Filsafat dan Teori Pembelajaran Matematika (Berparadigma Eksploratif dan Investigatif). Jakarta: Leuser Cipta Pustaka.

Yusuf, Mohammed Waziri, et al. (2010). Ethnomathematics (a Mathematical Game in Hausa Culture). International Journal of Mathematical Science Education Technomathematics Research Foundation.

Wahyuni, Astri; Tias, Ayu Aji Wedaring \& Sani, Budiman. 2013. Peran etnomatematika dalam membangun karakter bangsa. [Online]. Tersedia di: http:// eprints.uny.ac.id/10738/1/P\%20-\%2015.pdf. 